\title{
Perbandingan Status Besi pada Remaja Perempuan Obes dengan Gizi Normal
}

\author{
Dessy Afrianti, Herry Garna, Ponpon Idjradinata \\ Departemen Ilmu Kesehatan Anak Fakultas Kedokteran Universitas Padjajaran, RS Dr. Hasan Sadikin, \\ Bandung
}

\begin{abstract}
Latar belakang. Prevalensi obesitas pada remaja cenderung meningkat. Beberapa penelitian menyatakan bahwa terdapat hubungan antara obesitas dan terjadinya anemia defisiensi besi. Anemia defisiensi besi berhubungan dengan kebutuhan yang meningkat sejalan dengan peningkatan berat badan, serta pola makan yang tidak seimbang pada obesitas.

Tujuan. Mengukur dan membandingkan status besi yang dinilai berdasarkan pemeriksaan hemoglobin $(\mathrm{Hb})$, reticulocyte hemoglobin content $(\mathrm{CHr})$, dan feritin serum pada remaja perempuan obes dan gizi normal serta penanggulangan sedini-dininya pada remaja dengan defisiensi besi.

Metode. Penelitian studi analitik cross-sectional di SMP 14, SMP 34, dan SMA 24 Bandung pada bulan November 2011. Subjek penelitian terdiri atas remaja perempuan sehat yang memiliki status gizi normal dan obes berdasarkan standar WHO reference 2007 yang diambil secara acak sebanyak 25 orang tiap kelompok. Analisis data menggunakan uji nonparametrik dengan uji Mann Whitney untuk membandingkan status besi yang dinilai berdasarkan pemeriksaan $\mathrm{Hb}, \mathrm{CHr}$, dan feritin serum antara kelompok obes dan gizi normal. Dilakukan dietary recall untuk mengetahui asupan makanan pada kedua kelompok penelitian. Kemaknaan ditentukan berdasarkan nilai $\mathrm{p}<0,05$.

Hasil. Kadar $\mathrm{Hb}, \mathrm{CHr}$, dan feritin serum antara kelompok obes dan gizi normal tidak menunjukkan perbedaan $(p>0,05)$. Obesitas lebih banyak terjadi pada remaja dengan status sosioekonomi lebih tinggi $(p=0,039)$. Terdapat perbedaan asupan protein hewani, protein nabati, besi, dan vitamin $C$ antara remaja perempuaan obes dengan gizi normal yang memiliki nilai $p$ berturut-turut $p<0,001 ; p<0,019 ; p=0,026$ dan $\mathrm{p}=0,032$.

Kesimpulan. Tidak terdapat perbedaan status besi remaja perempuan obes dengan gizi normal. Asupan makanan mempengaruhi status besi pada remaja obes dan gizi normal. Sari Pediatri 2012;14(2):97-103.
\end{abstract}

Kata kunci: obesitas, remaja perempuan, status besi

\begin{abstract}
Alamat korespondensi:
Dr. Dessy Afrianti, peserta PPDS Departemen Ilmu Kesehatan Anak Fakultas Kedokteran Universitas Padjajaran/ RS dr. Hasan Sadikin, Jl. Pasteur 38 Bandung 40163, Telp. (022) 2035957, Fax. (022) 2034426. E-mail:afrianti.dessy@yahoo.com
\end{abstract}

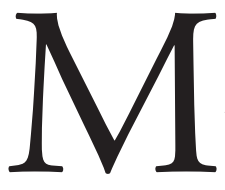

asa remaja disebut juga masa adolescence (adolecere=tumbuh menjadi dewasa), yaitu suatu periode transisi dari masa anak ke dewasa, yang ditandai dengan 
perkembangan biologis, psikologis, kognitif, dan sosial. ${ }^{1}$ Salah satu masalah yang sering ditemui oleh remaja adalah masalah gizi termasuk obesitas. Di Indonesia persoalan peningkatan prevalensi obesitas termasuk pada remaja terutama terjadi di kota besar seperti Bandung, Jakarta, dan sekitarnya. ${ }^{2}$

Kasus obesitas pada remaja lebih banyak ditemukan pada perempuan $(10,2 \%)$ dibandingkan dengan lakilaki $(6,8 \%)$. Tidak hanya menjadi masalah nasional, obesitas kini juga telah menjadi masalah kesehatan di seluruh dunia. ${ }^{3}$

Insidens obesitas pada remaja cenderung meningkat disebabkan oleh pola hidup kurang gerak sehingga aktivitas fisik anak berkurang. Waktu yang dihabiskan untuk menonton televisi atau menggunakan komputer semakin meningkat terutama pada remaja perempuan. ${ }^{4-6}$ Di samping itu lebih banyak tersedia makanan siap saji dengan energi dan kadar lemak yang tinggi serta kebiasaan makan yang buruk menjadi salah satu penyebab obesitas pada remaja. ${ }^{7}$ Obesitas pada remaja cenderung menetap hingga dewasa dan semakin lama obesitas berlangsung maka akan semakin besar korelasinya dengan mortalitas dan morbiditas. ${ }^{6-9}$ Obesitas sering dikaitkan dengan meningkatnya kejadian defisiensi besi. ${ }^{10,11}$ Hal tersebut sesuai dengan beberapa penelitian yang menunjukkan hubungan rendahnya status besi dengan obesitas pada remaja.

Prevalensi anemia defisiensi besi pada remaja di Indonesia cukup tinggi. Laporan Survei Kesehatan Rumah Tangga (SKRT) 2004 menunjukkan angka $45,8 \%$ dan $57,1 \%$ masing-masing pada remaja laki-laki dan perempuan usia 10-14 tahun. Sehubungan dengan hal tersebut di atas maka kebutuhan besi pada remaja laki-laki dan perempuan lebih tinggi yaitu sebesar 10-12 mg/hari dan $15 \mathrm{mg} /$ hari. $^{10,11}$

Asupan makanan seseorang dapat dinilai melalui penilaian konsumsi makanan yang dilakukan dengan mengumpulkan data mengenai jumlah dan jenis makanan yang dikonsumsi. Pengumpulan data asupan makanan dapat memberikan gambaran mengenai kebiasaan dan perkiraan kecukupan gizi pada seseorang.

Pemeriksaan yang cukup sensitif untuk menilai defisiensi besi pada tahap awal yaitu feritin serum dengan sensitivitas $71,4 \%$ dan spesifisitas $100 \%{ }^{12}$ Pemeriksaan lain yang dapat menilai defisiensi besi pada tahap yang awal yaitu kadar reticulocyte hemoglobin content $(\mathrm{CHr})$. Pemeriksaan ini dikatakan paling sensitif untuk menilai defisiensi besi ataupun anemia defisiensi besi pada anak dengan sensitivitas $83 \%$ dan spesifisitas $68 \% .{ }^{12,13}$ Dengan pertimbangan bahwa baik obesitas maupun defisiensi besi sama-sama berakibat buruk bagi kesehatan, maka hubungan antara keduanya penting untuk digali lebih jauh.

\section{Metode}

Penelitian potong lintang dilakukan di SMP 14, SMP 34, dan SMA 24 Bandung pada bulan November 2011. Subjek penelitian terdiri atas remaja perempuan sehat berusia 10-18 tahun yang memiliki status gizi normal dan obes berdasarkan standar WHO reference 2007 yang diambil secara acak sebanyak 25 orang tiap kelompok. Subjek yang telah terpilih dicatat identitasnya dalam formulir yang telah disediakan sebelumnya. Pada setiap subjek yang memenuhi kriteria inklusi diberikan penjelasan terperinci mengenai penelitian dan setelah menyetujui diminta untuk menandatangani lembar persetujuan/informed consent. Subjek dieksklusi apabila saat ini sedang mengonsumsi suplemen besi atau menderita penyakit kelainan darah. Subjek kemudian dilakukan pemeriksaan $\mathrm{Hb}, \mathrm{CHr}$, dan feritin serum untuk menilai status besi, serta recall makanan menggunakan recall 24 jam selama 7 hari berturut-turut. Data dianalisis menggunakan uji nonparametrik dengan uji Mann Whitney dengan kemaknaan ditentukan berdasarkan nilai $\mathrm{p}<0,05$.

\section{Hasil}

Penelitian kami melibatkan 973 orang remaja berusia 10-18 tahun di sekolah tersebut. Setelah dilakukan penapisan awal berdasarkan pemeriksaan antropometris, didapatkan remaja kelompok gizi kurang 68 (6\%), kelompok gizi normal 696 (71\%), kelompok berisiko gizi lebih (risk of overweight) 177 (18\%), dan kelompok obes 32 (3\%). Setelah dilakukan anamnesis dan pemeriksaan fisis pada kelompok gizi normal ditemukan 10 orang belum menstruasi sehingga tidak diikutsertakan ke dalam penelitian dan hanya sebanyak 686 orang yang dipilih secara acak untuk mengikuti penelitian. Pada kelompok obes terdapat 3 belum menstruasi, 1 menderita penyakit kelainan darah, 
Tabel 1. Karakteristik orangtua subjek penelitian

\begin{tabular}{lccc}
\hline Variabel & $\begin{array}{c}\text { Obesitas } \\
(\mathrm{n}=25) \\
\mathrm{n}\end{array}$ & $\begin{array}{c}\text { Gizi normal } \\
(\mathrm{n}=25)\end{array}$ & Nilai $\mathrm{p}^{*}$ \\
& $\mathrm{n}$ & \\
\hline Pekerjaan ayah & & 10 & 0,189 \\
$\quad$ Pegawai negeri & 8 & 7 & \\
$\quad$ Pegawai swasta & 5 & 8 & \\
$\quad$ Wiraswasta & 9 & 0 & \\
$\quad$ ABRI & 3 & & 0,380 \\
Pendidikan ayah & & 0 & \\
$\quad$ SMP & 1 & 13 & \\
$\quad$ SMA & 10 & 12 & \\
$\quad$ Sarjana & 14 & & 0,653 \\
Pendidikan ibu & & & \\
$\quad$ SMP & 1 & 2 & \\
$\quad$ SMA & 12 & 11 & \\
$\quad$ Sarjana muda & 3 & 1 & \\
$\quad$ Sarjana & 9 & 11 & \\
Penghasilan keluarga & & & 0,039 \\
(juta rupiah) & & & \\
$\quad<1,160$ & 3 & 3 & \\
$\quad>1,160-2,885$ & 10 & 18 & \\
$\quad>2,885$ & 12 & 4 & \\
\hline
\end{tabular}

Keterangan:*) Berdasarkan uji chi-square

Tabel 2. Karakteristik umum subjek penelitian

\begin{tabular}{|c|c|c|c|}
\hline Karakteristik & $\begin{array}{l}\text { Obes } \\
n=25\end{array}$ & $\begin{array}{c}\text { Gizi normal } \\
n=25\end{array}$ & $\begin{array}{c}\text { Nilai } \\
\mathrm{p}^{*}\end{array}$ \\
\hline Usia (tahun) & & & 0,049 \\
\hline Rerata (SB) & $13,52(1,5)$ & $14,2(1,2)$ & \\
\hline Median & 13 & 14 & \\
\hline Rentang & $11-17$ & $13-17$ & \\
\hline \multicolumn{4}{|l|}{ Berat badan $(\mathrm{kg})$} \\
\hline Rerata (SB) & $82,2(8,3)$ & $49,3(4,8)$ & \\
\hline Median & 82 & 50 & \\
\hline Rentang & 66-104 & $41-58$ & \\
\hline Tinggi badan $(\mathrm{cm})$ & & & 0,355 \\
\hline Rerata (SB) & $151,0(6,6)$ & $152,7(4,2)$ & \\
\hline Median & 151 & 152 & \\
\hline Rentang & $129-165$ & $147-160$ & \\
\hline \multicolumn{4}{|l|}{ IMT $\left(\mathrm{kg} / \mathrm{m}^{2}\right)$} \\
\hline Rerata (SB) & $36,2(1,7)$ & $21,1(1,7)$ & \\
\hline Median & 35,6 & 20,8 & \\
\hline Rentang & $33-39,7$ & $18,1-24,0$ & \\
\hline
\end{tabular}

Keterangan:*) berdasarkan uji Mann-Whitney dan 3 menolak ikut serta dalam penelitian sehingga hanya tersisa 25 orang. Pada kelompok gizi normal dilakukan pemilihan secara acak, dengan ukuran sampel disesuaikan dengan jumlah kasus obesitas yaitu 25 orang.

Tabel 3. Perbandingan asupan makanan remaja perempuan obes dan gizi normal

\begin{tabular}{|c|c|c|c|}
\hline Asupan makanan & $\begin{array}{l}\text { Obes } \\
\mathrm{n}=25\end{array}$ & $\begin{array}{c}\text { Gizi normal } \\
n=25\end{array}$ & $\begin{array}{l}\text { Nilai } \\
\mathrm{p}^{*}\end{array}$ \\
\hline Vit C (mg): & & & 0,032 \\
\hline Rerata (SB) & $441,7(26,2)$ & $119,8(63,2)$ & \\
\hline Median & 460,5 & 121,3 & \\
\hline Rentang & $118,6-793,0$ & $29-280,5$ & \\
\hline $\mathrm{Fe}(\mathrm{mg}):$ & & & 0,026 \\
\hline Rerata (SB) & $50,5(19,6)$ & $24,1(10,0)$ & \\
\hline Median & 47,4 & 17,5 & \\
\hline Rentang & $23,6-95,0$ & $12,6-56,0$ & \\
\hline Protein nabati (g) & & & 0,019 \\
\hline Rerata & $140,6(48,5)$ & $180,7(54,3)$ & \\
\hline Median & 148,5 & 180,7 & \\
\hline Rentang & $71,8-252$ & $97,7-301,3$ & \\
\hline Protein hewani (g) & & & $<0,001$ \\
\hline Rerata & $205,9(81,9)$ & $127,4(51,5)$ & \\
\hline Median & 189,6 & 111 & \\
\hline Rentang & $88,2-410,1$ & $45,1-204,7$ & \\
\hline Teh (gelas) & & & 0,591 \\
\hline Rerata & $9,9(3,9)$ & $10,0(3,3)$ & \\
\hline Median & 8 & 9 & \\
\hline Rentang & $5-20$ & $4-18$ & \\
\hline
\end{tabular}

Keterangan:*) nilai p menggunakan uji Mann-Whitney

Tabel 4. Perbandingan menstruasi antara remaja perempuan obes dan gizi normal

\begin{tabular}{lccc}
\hline Menstruasi & $\begin{array}{c}\text { Obes } \\
\mathrm{n}=25\end{array}$ & $\begin{array}{c}\text { Gizi normal } \\
\mathrm{n}=25\end{array}$ & $\mathrm{p}^{*}$ \\
\hline Lama menstruasi (hari): & \multicolumn{3}{c}{0,095} \\
$\quad$ Rerata (SB) & $6,64(0,77)$ & $6,48(0,52)$ & \\
$\quad$ Median & 7 & 6 & \\
$\quad$ Rentang & $5-8$ & $5-8$ & \\
$\begin{array}{l}\text { Jumlah pembalut yang } \\
\text { digunakan setiap hari } \\
\text { (lembar) }\end{array}$ & & & 0,128 \\
$\quad$ Rerata (SB) & $3,44(0,56)$ & $3,64(0,69)$ & \\
$\quad$ Median & 3 & 3 & \\
Rentang & $3-4$ & $3-4$ & \\
\hline
\end{tabular}

Keterangan:*) berdasarkan uji Mann-Whitney 
Tabel 5. Hasil pemeriksaan kadar hemoglobin, reticulocyte hemoglobin content, dan feritin serum

\begin{tabular}{|c|c|c|c|}
\hline Hasil pengukuran & $\begin{array}{l}\text { Obes } \\
(\mathrm{n}=25)\end{array}$ & $\begin{array}{l}\text { Gizi normal } \\
\quad(\mathrm{n}=25)\end{array}$ & $\mathrm{p}^{*}$ \\
\hline \multicolumn{4}{|l|}{ Hemoglobin $(\mathrm{g} / \mathrm{dL})$} \\
\hline Rerata (SB) & $13,67(0,86)$ & $13,78(0.68)$ & 0,460 \\
\hline Median & 13,6 & 13,8 & \\
\hline Rentang & $12,3-15,6$ & $12,5-15,1$ & \\
\hline \multicolumn{4}{|l|}{$\mathrm{CHr}(\mathrm{pg})$} \\
\hline Rerata (SB) & $31,05(1,76)$ & $31,52(1,45)$ & 0,398 \\
\hline Median & 31,7 & 3,0 & \\
\hline Rentang & $23,7-34,0$ & $24,4-33,8$ & \\
\hline \multicolumn{4}{|l|}{ Feritin serum $(\mu \mathrm{g} / \mathrm{L})$} \\
\hline Rerata (SB) & $38,09(1,53)$ & $39,02(1,27)$ & 0,428 \\
\hline Median & 23,58 & 40,17 & \\
\hline Rentang & $10,74-82,79$ & $11,42-84,11$ & \\
\hline
\end{tabular}

Keterangan:") Uji Mann-Whitney

\section{Pembahasan}

Berdasarkan karakteristik umum subjek penelitian didapatkan usia subjek rata-rata pada kelompok remaja perempuan obes lebih muda dibandingkan dengan kelompok gizi normal. Pekerjaan ayah, pendidikan ayah, dan pendidikan ibu tidak menunjukkan perbedaan. Obesitas lebih banyak terjadi pada keluarga remaja perempuan obes dengan tingkat penghasilan keluarga yang lebih tinggi dibandingkan dengan keluarga remaja perempuan gizi normal.

Tingginya penghasilan orangtua secara tidak langsung mempengaruhi gaya hidup dan nutrisi pada remaja. Gaya hidup kurang gerak dengan kemajuan teknologi dan transportasi cenderung menurunkan kebutuhan gerak dalam kehidupan remaja seharihari. Meningkatnya aktivitas menonton televisi dan bermain komputer berperan menambah gaya hidup kurang gerak di kalangan remaja. Di samping perubahan gaya hidup, terdapat pula perubahan pola makan dengan pilihan makanan yang bertambah dan kurang sehat terutama di kota besar. Remaja menjadi sering mengonsumsi makanan cepat saji yang lebih banyak mengandung energi, lemak, karbohidrat, gula, namun rendah serat, buah, dan sayuran sehingga meningkatkan risiko untuk terjadi obesitas. ${ }^{6,7,9}$

Penelitian Tee ${ }^{8}$ menyatakan bahwa di Asia obesitas lebih sering ditemukan di daerah perkotaan dan pada populasi dengan tingkat sosioekonomi yang lebih tinggi. Berbeda dengan di Amerika Serikat dan
Israel yang mendapatkan bahwa remaja obes lebih banyak ditemukan pada golongan sosioekonomi rendah. Penduduk Amerika Serikat yang memiliki sosioekonomi tinggi cenderung lebih memperhatikan kesehatan dengan mengonsumsi makanan dengan gizi seimbang serta mendatangi pusat-pusat kebugaran dibandingkan dengan sosioekonomi rendah. ${ }^{3,5}$

Kecenderungan seorang remaja perempuan obes untuk mengalami anemia cukup tinggi. Pada penelitian yang dilakukan oleh Eftekhari $\mathrm{dkk}^{13}$ didapatkan bahwa pada remaja perempuan obes sering terjadi anemia defisiensi besi. Selama pubertas seorang remaja memerlukan lebih banyak besi untuk pertumbuhan yang cepat dan peningkatan volume darah. Kebutuhan besi tubuh juga secara langsung berhubungan dengan berat badan. Peningkatan berat badan akan meningkatkan kebutuhan tubuh terhadap besi. Setiap kilogram penambahan berat badan diperlukan peningkatan besi tubuh sebanyak 35-45 mg. Beberapa penelitian yang pernah dilakukan juga menunjukkan hubungan rendahnya status besi dengan obesitas pada remaja. Hasil penelitian Pinhas-Hamiel $\mathrm{dkk} \cdot{ }^{14}$ menunjukkan bahwa kadar besi secara bermakna mempunyai korelasi negatif dengan skor-Z indeks massa tubuh (IMT), yaitu setiap peningkatan skor-Z IMT terdapat penurunan kadar besi. Pengaruh kegemukan terhadap kandungan besi tubuh juga pernah dilaporkan oleh Erickson $\mathrm{dkk}^{10}$ yang melakukan penelitian pada tikus. Dari penelitian tersebut didapatkan bahwa pada usia yang sama, kebutuhan besi tikus gemuk lebih tinggi daripada tikus tidak gemuk yang terlihat dari penyerapan besi makanan yang lebih kurang dua kali lipat lebih banyak pada tikus gemuk.

Kebiasaan makan yang tidak seimbang dapat mempengaruhi asupan besi pada remaja. Survei mengenai asupan gizi di Amerika Serikat menunjukkan bahwa remaja cenderung mendapat asupan besi lebih sedikit dari yang dianjurkan. Kebiasaan makan makanan yang mengandung besi dengan bioavailabilitas rendah sering terjadi di kalangan remaja. Remaja umumnya mengonsumsi makanan yang berasal dari karbohidrat dan lemak. ${ }^{18}$

Kemampuan tubuh dalam mengabsorbsi besi bergantung pada jumlah dan bioavailabilitas besi serta terdapatnya pendorong atau penghambat absorbsi besi dalam makanan. Bioavailabilitas besi heme sebesar $20 \%-30 \%$, sedangkan non-heme hanya $1 \%-10 \%$. Meskipun makanan campuran hanya mengandung $10 \%$ besi heme dari jumlah besi makanan tersebut, 
tetapi merupakan 25\% dari besi total yang diserap tubuh. Sebagian besar besi dari makanan yang mengandung besi non-heme masuk ke dalam saluran pencernaan dalam bentuk ion $\mathrm{Fe}^{3+}$ yang tidak dapat langsung diserap sehingga harus direduksi menjadi ion $\mathrm{Fe}^{2+}$. Beberapa zat dalam makanan mempunyai kemampuan mereduksi antara lain asam askorbat dan beberapa asam amino seperti sistein dan histidin. Absorpsi besi dipermudah oleh asupan asam askorbat dengan terdapatnya gugus sulfidril dan asam amino sulfur sehingga dapat mereduksi besi bentuk feri menjadi fero yang kemudian membentuk kompleks fero askorbat. Kombinasi $200 \mathrm{mg}$ asam askorbat dengan garam besi dapat meningkatkan penyerapan besi sebesar 25\%-50\%. Vitamin C merupakan zat yang paling poten untuk meningkatkan absorbsi besi non-heme, sedangkan phytale yang banyak ditemukan dalam teh merupakan zat yang paling poten untuk menginhibisi besi non-heme.

Setelah dilakukan food recall pada subjek penelitian, didapatkan bahwa remaja perempuan obes ternyata lebih banyak mengonsumsi protein hewani daripada protein nabati serta lebih banyak mengonsumsi vitamin $\mathrm{C}$ dibandingkan dengan remaja perempuan gizi normal. Hal tersebut berarti bahwa asupan besi pada remaja perempuan obes lebih baik dibandingkan dengan remaja perempuan gizi normal karena mengonsumsi besi dengan bioavailabilitas yang lebih baik. Penelitian yang dilakukan oleh Peneau $\mathrm{dkk}^{19}$ mengenai hubungan asupan vitamin $\mathrm{C}$ dengan kadar feritin dalam tubuh didapatkan bahwa pada subjek penelitian yang mengonsumsi lebih banyak vitamin $\mathrm{C}$ ternyata memiliki kadar feritin yang lebih tinggi.

Penelitian Tatala $\mathrm{dkk}^{18}$ di Tanzania menyatakan bahwa anemia defisiensi besi berhubungan erat dengan rendahnya asupan makanan yang mengandung besi dengan bioavailabilitas serta asupan yang tinggi makanan menghambat penyerapan besi seperti teh dan sereal di antara waktu makan. Penelitian Erickson dkk ${ }^{10}$ menunjukkan bahwa pada tikus yang secara genetik mengalami obesitas tidak ditemukan defisiensi besi karena diberi makanan yang cukup mengandung besi, walaupun kebutuhan besi lebih tinggi pada tikus obes dibandingkan tikus yang tidak obes.

Berdasarkan hasil pemeriksaan kadar hemoglobin, reticulocyte hemoglobin content, dan feritin serum pada remaja perempuan obes dan gizi normal didapatkan status besi pada kedua kelompok tersebut ternyata tidak berbeda. Hal tersebut berbeda dengan hasil penelitian di Amerika Serikat dan Israel yang menunjukkan bahwa remaja obes mempunyai status besi lebih rendah daripada remaja gizi normal. Perbedaan latar belakang status sosioekonomi keluarga pada remaja obes di negara maju dibandingkan dengan di Indonesia menyebabkan perbedaan hasil penelitian. Di Amerika Serikat, obesitas lebih banyak terjadi pada sosioekonomi rendah. Hubungan antara status sosioekonomi dan terjadinya defisiensi besi pernah dilaporkan oleh Frith $\mathrm{dkk}^{15}$ yang mendapatkan bahwa penduduk Mexico yang berstatus sosioekonomi rendah memiliki kadar besi yang lebih rendah dibandingkan dengan status sosioekonomi tinggi. Hal tersebut disebabkan karena mereka mengonsumsi makanan yang mengandung besi dengan bioavailabilitas rendah. Di Indonesia terjadi hal sebaliknya, obesitas lebih banyak terjadi pada status sosioekonomi tinggi yang asupan besinya diduga lebih baik dibandingkan dengan remaja obes di Amerika Serikat dan Israel.

Obesitas berhubungan dengan terjadinya peningkatan inflamasi sistemik. Penelitian yang dilakukan oleh McClung dan Karl ${ }^{16}$ membuktikan bahwa jaringan lemak melepaskan berbagai macam sitokin yang menyebabkan inflamasi sistemik yang berhubungan dengan patogenesis penyakit metabolik dan penyakit degeneratif yang terjadi pada obesitas. Salah satu sitokin yang dilepaskan jaringan lemak ke dalam sirkulasi portal yaitu interleukin-6 yang akan menstimulasi hati untuk memproduksi acute-phase reactan dan kadar interleukin-6 dalam sirkulasi portal yang kadarnya lebih tinggi secara bermakna pada orang obes dibandingkan dengan status gizi normal. Salah satu acute phase reactan yang dilepaskan hati karena perangsangan interleukin-6 yaitu hepsidin (25 amino acid peptide). Hepsidin menghambat penyerapan besi di enterosit dan juga berinteraksi dengan transmembrane iron exporter ferropotin untuk menghambat pelepasan feritin dari makrofag sehingga kadar feritin di jaringan tetap tinggi. Di samping itu sitokin terutama TNF- $\alpha$ yang dilepaskan selama proses inflamasi juga akan berpengaruh pada regulasi feritin, yaitu akan meningkatkan penghancuran feritin di makrofag. Pada penelitian lain juga dikatakan bahwa leptin yang merupakan adipokin yang dihasilkan oleh jaringan lemak juga berperan penting untuk menstimulasi pengeluaran hepsidin pada penderita obes. Miraglia $\mathrm{dkk}^{17}$ yang meneliti hubungan kadar leptin dan hepsidin dengan status besi pada remaja obes mendapatkan hubungan yang 
kuat antara keduanya. Pada subjek dengan status besi yang rendah didapatkan kadar leptin dan hepsidin yang lebih tinggi.

Berdasarkan hasil pemeriksaan kadar feritin serum dan $\mathrm{CHr}$ diketahui bahwa empat orang remaja perempuan kelompok obes dan dua orang remaja perempuan gizi normal mengalami defisiensi besi (feritin serum $<12 \mu / \mathrm{L}$ ) tetapi tidak mengalami anemia, sedangkan dari pemeriksaan $\mathrm{CHr}$ diketahui dua orang remaja kelompok obes dan satu orang remaja kelompok gizi normal mengalami defisiensi besi (kadar $\mathrm{CHr}$ $<26$ pg) tanpa anemia. Remaja obes yang mengalami defisiensi besi dengan kadar feritin serum $<12 \mu / \mathrm{L}$ dan kadar $\mathrm{CHr}<26$ pg ternyata mengonsumsi protein hewani dan asupan vitamin $\mathrm{C}$ yang lebih sedikit dibandingkan remaja perempuan obes dengan kadar feritin dan $\mathrm{CHr}$ yang normal.

Pada penelitian kami kebutuhan besi pada remaja perempuan obes yang meningkat dapat dikompensasi oleh asupan besi yang lebih tinggi dibandingkan dengan remaja perempuan gizi normal, sehingga tidak menunjukkan perbedaan status besi yang bermakna berdasarkan kadar $\mathrm{Hb}, \mathrm{CHr}$, maupun feritin antara remaja perempuan obes dan gizi normal.

Keterbatasan penelitian kami adalah tidak dilakukan quality control pada saat melakukan recall asupan makanan setiap hari. Selain itu, data asupan makanan dengan metode recall 24 jam sangat bergantung pada daya ingat subjek penelitian sehingga mungkin diperoleh informasi yang tidak akurat

\section{Kesimpulan}

Defisiensi besi pada remaja perempuan obes dapat diatasi dengan pola makan yang mengandung lebih banyak protein hewani dibandingkan nabati, banyak mengonsumsi buah dan sayur yang mengandung vitamin $C$, serta menghindari diet yang tidak sehat.

\section{Daftar pustaka}

1. Soetjiningsih. Tumbuh kembang remaja dan permasalahannya. Cetakan ke-2. Jakarta: Sagung Seto; 2007.

2. Badan Pusat Statistik Jawa Barat. Jawa Barat dalam angka. Bandung: Badan Pusat Statistik Jawa Barat; 2008.

3. Sobal J. Globalization and the epidemiology of obesity. Int J Epidemiol 2001;30:1136-7.
4. Waters EB, Baur LA. Childhood and adolescent obesity: modernity's scourge. MJA. 2003;178:422-3.

5. Wang Y, Beydoun MA. The obesity epidemic in the United States-gender, age, socioeconomic, racial/ethnic, and geographic characteristic: a systematic review and meta-regression analysis. Epidemiologic reviews. Baltimore: Johns Hopkims Bloomberg School of Public Health; 2007.

6. Schneider MB, Brill SR. Obesity in children and adolescents. Pediatr Rev. 2005;26:155-62.

7. CDC. Trends in childhood obesity. 2009. Diunduh 12 Januari 2011. Didapat dari: www.cdc.gov/obesity/childhood/ trends.html.

8. Tee ES. Obesity in Asia: prevalence and issue in assessment methodologies. Asia Pasific J Clin Nutr 2002;11:5694-701.

9. Alemzadeh R, Rising R, Lifshitz F. Obesity in children. Dalam: Lifshitz F, penyunting. Pediatric endocrinology. Edisi ke-5. Volume 1. New York: Informa Healthcare; 2007. h. 1-25.

10. Erickson JC, Hollopeter G, Palmiter RD. Iron metabolism in genetically obese (ob/ob) mice. J Nutr 2006;274:1704-7.

11. Baynes RD, Cook JD, Skikne BS. Iron deficiency and the measurement of iron status. Nutrit Research Rev 2002;5:189-202.

12. Lanzkowsky P. Manual of pediatric hematology and oncology. Edisi ke-4. California: Elsevier; 2005.

13. Eftekhari MH, Mozaffari-Khosravi M, Shidfar F. The relationship between BMI and iron status in iron-deficient adolescent Iranian girls. Pub Hlth Nutr 2008;12:2377-81.

14. Pinhas-Hamiel O, Newfield RS, Koren I, Agmon A, Lilos P, Phillip M. Greater prevalence of iron deficiency in overweight and obese children and adolescents. J Obesity 2003;27:416-8.

15. Frith AL, Cogswell ME, Khan LK, Will CJ, Ramakrishnan $\mathrm{U}$. Iron deficiency anemia: higher prevalence in Mexican American than in non-Hispanic white females in the third National Health and Nutrition Examination Survey. Am J Clin Nutr 2002;72:963-8.

16. McClung JP, Karl JP. Iron deficiency and obesity: the contribution of inflammation and diminished iron absorption. Nutr Rev 2008;67:100-4.

17. Miraglia E, Santoro N, Amato A, Brienza C, Calabro $\mathrm{P}$, Wiegerinck ET, dkk. Hepcidin in obese children as a potential mediator of the association between obesity and iron deficiency. J Clin Endocrinol Metab 2009; 94:5102-7. 
18. Tatala S, Svanberg U, Mduma B. Low dietary iron availability is a major cause of anemia: a nutrition survey in the Lindi District of Tanzania. Am J Clin Nutr 2008;68:171-8.

19. Péneau S, Dauchet L, Vergnaud AC, Estaquio C, Kesse-Guyot E, Bertrais S, dkk. Relationship between iron status and dietary fruit and vegetables based on their vitamin $\mathrm{C}$ and fiber content. Am J Clin Nutr 2008;87:1298-305.

20. Nead KG, Halterman JS, Kaczorowski JM, Auinger P, Weitzman M. Overweight children and adolescents: a risk group for iron deficiency. Pediatrics 2004;114:104-8. 